\title{
THE LITURGICAL DIMENSION OF THE BYZANTINE ICON IN THE ECONOMY OF SALVATION
}

\section{Leontin POPESCU*}

\begin{abstract}
Liturgical art, to the extent to which it remains tied to liturgical worship, can be assessed both as: beauty coming from the first beauty and mystery; it does not hide but reveals. The purpose of the Holy Icons in addition to the confession of the church dogmas, along with the mystical experience is undoubtedly the call or standing invitation to prayer. For the Orthodox Church, the Icon is an expression of righteous confession of faith and an integral part of the liturgical space, videlicet of the Church and an essential element in the actual act of prayer. The icon is neither an absolute, nor an annex, but a continuous and complete expression of faith and proclamation of the divine economy. For that reason, the life in Christ, whom we worship in the icons is not a utopia, but a reality and therefore icons of the saints do not have a decorative role in the Church, but they express the conviction that holiness is within the reach of all men. Liturgy, together with the entire Orthodox liturgical ensemble, and liturgical art are two values that, within celebrating worship, make up a unique reality. Their very close connection is revealed by the fact that while the former is trying to discover the spiritual world, the latter depicts this spiritual world in colours and shapes accessible to all. We can say that the very structure of the Church is directly determined by the Holy Liturgy, but the Holy Liturgy also determines the iconographic apparatus: the frescos and the icons are directly involved in liturgical performance, beyond any decorative and aesthetic function. And, from this point of view, the Byzantine icon may be called a theological synopsis and a theology in images.
\end{abstract}

Keywords: icon, worship, liturgy, prayer, art.

"PhD Professor, "Dunărea de Jos" University of Galati (Faculty of History, Philosophy and Theology), Galaţi, Romania. 


\section{Introduction}

The entire universe of the Orthodox Tradition is essentially liturgical. Within the life and spirituality of the Orthodox Church, the divine worship is at its core, and this is the place held by the Eucharist, the centre and specific environment of ecclesiastic life. In its extension, the divine worship encompasses all those acts that connect man to God ${ }^{1}$, a catalyst of the whole faith with all its segments: doctrine, spirituality, church practice, sacred art. Due to its importance and the place that worship holds within the life of the Church, Christianity has been defined $^{2}$ as a"liturgical religion, community performing the act of worship;" theology, mysticism and discipline, art and all these ecclesiastic segments become important by worship celebration. That is why the Orthodox Liturgy is full of symbols, of meanings, of secrecy, because it is a theology of Christ's sacrifice. The antiphons, the litanies and the prayers of the Holy Liturgy express a profound theology that centres on Jesus Christ, God-Man who sacrificed Himself for us $^{3}$. From this point of view, the Orthodox Liturgy appears as an anticipated experience of the Kingdom of God by apophatic sight.

\section{The relationship between the Byzantine icon and Christian worship}

Symbolism is neither parabolic nor allegorical, but iconic in the sense of partaking in Christ's sacrifice ${ }^{4}$. The Eucharistic gathering represents, in this respect, more than a sign or symbol, but an icon of those on their path to salvation. From this point of view, the Orthodox Liturgy, in its acceptance of liturgical unit - the place of worship as a space designated for practice, sacred art, psalm singing, reciting, the

${ }^{1}$ Ene BRAnISTE, Liturgica specială (Special Liturgics), Bucureşti, IBMBOR Publishing House (hereinafter, Ph.), 1980, p. 91; also see PS. Laurențiu STREZA, "Cinstirea lui Dumnezeu. Cultul și formele lui (Honoring God. The Denomination and Its Forms)", in vol. Credința ortodoxă și viața creștină (Orthodox Faith and Christian Life), Sibiu, 1992, p. 223-259, here p. 259.

2 Georgij FlorovskiJ, "The Elements of Liturgy", in P. Edwall, E. Haymann, Wd. MAXWELL, Ways of Worship, London. 1952, p. 52.

3 Traian VALDMAN, "La celebrazione eucaristica culmine della vita comunionale ortodossa", in vol. Eucaristia sfida alle Chiese divise, Padova, Messaggero Ph., 1984, p. 151-175, here p. 168.

${ }^{4}$ John Zizioulas, Eucaristia e Regno di Dio, Magnano (BI), Qiqajon-Bose Ph., 1996, p. 30. 
Gospel, the Holy Vessel, the necessary clothing, liturgical personnel, etc. - distinguishes itself from any profane vision, and that happens because by means of it the Unseen, the eternal becomes visible in visible and temporal things. Here is the ecphonis at the beginning of the Holy Liturgy: "Blessed is the kingdom of the Father, the Son and the Holy Spirit, now and forever and until the end of time". This is not the kingdom of an earthly ruler, no matter how powerful he may be, but space and time vanish, acquiring eschatological value: continuous present and real space merged with represented space. That is why the Liturgy is only performed in the Sanctified Church, meaning adorned with icons and frescos that, along with all the dynamics of the Liturgy, confer that dimension of time and space: "the time of God merging with the time of man" , the Heavenly Church united with the earthly one. Everything that makes up the church, all its descriptive parts are integrated in the secret of the Liturgy. The Liturgy itself is an icon of everything that God has done for His creation ${ }^{7}$. As the Holy Liturgy cannot be performed without prayers, it cannot take place without icons.

Introducing people to the Heavenly Kingdom, to transfiguration, icons thus allow the passing from the finite to the divine reality. That is why they are called "gates to eternity" " "windows to the absolute", because they continuously bring the divine reality before those who believe, clearly contributing to the beauty of the Byzantine Liturgy, to that misterium fascinosum ${ }^{10}$ of the Holy Liturgy.

In its ensemble, as a place of worship, the church is the liturgical space that includes the gathering of believers and symbolically encompasses the entire universe; the dwelling represents the cosmic

${ }^{5}$ Liturghier (Missal), Bucureşti, IBMBOR Ph., 2000, p. 125.

6 Alceste CATElla, "Eucaristia Domenicale vertice della vita cristiana", in Rinaldo FALSINI, Il mistero cristiano e la sua celebrazione, Milano, Edizioni OR., 1994, p. 6685, here p. 68; also see Leonid UsPENSKI, Teologia icoanei în Biserica Ortodoxă (Icon Theology in the Orthodox Church), Apologeticum Ph., 2006, p. 149.

${ }^{7}$ Pavel Evdokimov, Ortodoxia (Orthodoxy), Bucureşti, IBMBOR Ph., 1996, p. 244.

8 John Baggley, Porți ale veșniciei. Icoanele și semnificația lor duhovnicească (Gates to Eternity. Icons and Their Spiritual Significance), Bucureşti, Sophia Ph., 2004.

9 Michel Quenot, Icoana. Fereastră spre absolut (The Icon. Window towards the Absolute), Bucureşti, Enciclopedică Ph., 1993.

${ }^{10}$ Angelo Амато, Gesu il Signore. Saggio di cristologia, Bologna, Edizioni Dehoniane, 1999, p. 357-358. 
aspect of the Church ${ }^{11}$. And, if we quote Dyonisius Pseudo-Areopagita, the word "cosmos" is equivalent to Beauty and Kindness par excellence.

"And we call beauty what is beautiful beyond the being, for beauty conveyed by itself to all that exists, and because it is the cause of all beauties and splendors, as a light that communicates itself by its rays as a spring that draws you to it (Kallos; that is called beautiful), unifying everything into one, calling all things onto themselves" ${ }^{\prime 2}$.

All terrestrial beauties reside in the divine beauty as their first cause. The icon, as a liturgical object, equally is a vehicle and an instrument to acquiring knowledge of divine Beauty and it is a path that leads to discovering God.

Liturgical art, to the extent to which it observes liturgical worship, may be assessed both as beauty that comes from the first beauty and mystery, which does not hide, but reveals ${ }^{13}$. The purpose of the Holy Icons, besides that of professing the church dogmas ${ }^{14}$, together with that of mystic experience, is undoubtedly that of constant call or invitation to prayer ${ }^{15}$. For the Orthodox Church, the Icon is an expression of confessing the right faith ${ }^{16}$ and an integral part of the liturgical space, videlicet of the church and a vital element in performing religious service, just as branches are connected to the tree trunk. Not only does the icon draw its inspiration from Church worship, but it also forms a homogenous unit with it, completing it, explaining it and enhancing its action on the souls of believers ${ }^{17}$. Outside the Church

${ }^{11}$ L. USPENSKI, Teologia icoanei... (Icon Theology...), p. 128.

${ }^{12}$ S. Dionysius AreOPagita, "De divinis nominibus", in J.P. Migne, $P G$. vol. 3, col.586996, here col.702D.

${ }^{13}$ Cipriano Vagaggini, Il senso teologico della liturgia, Milano, San Paulo Ph., 1999, p. 66.

${ }^{14}$ A. Amato, Gesu il Signore, p. 358.

15 DANIEL, Ciobotea (Patriarch of the Romanian Orthodox Church), Evanghelia slavei lui Hristos. Predici la Duminicile de peste an (The Gospel of Christ's Glory. Sermons on Sundays Over the Year), Bucureşti, Basilica Ph., 2016, p. 398.

${ }^{16}$ Ibidem, p. 394.

17 VASILE TÂRGOVIȘTEANUL, "Sfintele icoane în credința și evlavia ortodoxă" (The Holy Icons in the Orthodox Faith and Piety), in Indrumător pastoral (Pastoral Guidelines), Bucureşti, Diocese of București Ph., 1981, p. 83-86, here p. 86. 
space, the icon loses most of its significance ${ }^{18}$. Undoubtedly, any Christian has the right to possess and have in hishouse one or several icons, and their very existence is necessary, but only to the extent to which the life and house of the Christian are an extension of the church and of the Liturgy. Otherwise, the icon becomes merely decorative. Along the same lines, a gallery is an inappropriate place for icons. Moreover, if we assess the liturgical function of the icon, which is a primary one alongside music, sermon and catechesis, we can see that each icon holds a very well defined place within the liturgical year, the liturgical calendar of holidays and Sundays ${ }^{19}$.

Liturgy, together with all the Orthodox liturgical complex and liturgical art are two values that are one unique reality in worship celebration. Their close connection is revealed in the fact that, while the former attempts at discovering the spiritual world, the latter paints this spiritual world in colors and shapes accessible to all ${ }^{20}$. We may say that the very structure of the Church is directly determined by the Holy Liturgy, but the Holy Liturgy also determines the iconographic apparatus: the frescos and the icons are directly involved in the liturgical act, beyond any decorative and aesthetic function. Due to this, the Byzantine icon is considered to be a privileged space to experience God's grace and it essentially belongs to theology, spirituality, and Christian worship. From this point of view, the Byzantine icon may be called a theological synopsis and theology in images ${ }^{21}$. This is the very thing told to us by the Holy Fathers participating in the $7^{\text {th }}$ ecumenic Synod by the words of deacon Epifanie:

"What the Holy Scriptures, the Lives of holy men tell us in words, we remind people in the images of painting, the very work of God. As Basilius Magnus said: What history conveys to the hearing by means of the word, the same thing is conveyed by the painting in a silent mode via

18 Laurențiu DrĂGHICENOIU, "De la simbol la icoană" (From the Symbol to the Icon), in rev. Glasul Bisericii (The Voice of the Church), no. 1-6/2011, p. 155-184, here, p. 181.

${ }^{19}$ Georges GHARIB, Le icone festive della chiesa ortodossa, Milano, Ancora Ph., 1985, p. 36.

20 Vincenzo GatTi, "Arte", în Dominico SARtore e Achile M. TriaccA, Nuovo Dizionario di Liturgia, Milano, San Paolo Ph., p. 106, col.2.

${ }^{21}$ Ioan DuRĂ, "Icoană și Liturghie (Icon and Liturgy)" in rev. Ortodoxia (Orthodoxy), no. 1/1982, p. 84-89, here p. 87. 
representation" 22 .

The Holy Gospel is not just letter and word, but fact, history of the salvation where Christ reveals Himself in manifestations towards the others, disciples and the world. From this point of view, the Orthodox Icon may be considered as "painted Gospel, visible symbol-word"23. The condac of the Matins on the first Sunday of the Great Fast, also called the Sunday of Orthodxy "the $8^{\text {th }}$ day of the Church" 24 in remeberance of the icon's triumph on iconoclasm, best synthesizes the "reading" aspect inherent in the theology of the icon: "the word of the Holy Father, impossible to encompass, out of you, Mother of God, took body; and turning the first face, He merged it with the godly adornment. Therefore, confessing salvation, we imagine Him in fact and word" 25 . Who accepts the Scripture and listens to the lives of the holy men accepts the icon as well. Nobody can claim to be an Orthodox Christian without accepting and worshiping icons ${ }^{26}$. Worship, Scriptures and icons support one another, contributing to preaching $\mathrm{Christ}^{27}$.

Father Stăniloae associates the icon with the exegesis, stating that: "The Byzantine icon is solidary with the patristic exegesis at the beginning of the Holy Scripture. The icon clearly and simultaneously achieves by image what exegesis and patristic preaching successively strive to express in words" 28 . Hence, each icon repeats, in its own way, what the Holy Scripture is saying, but, in order for it to do this, it must not be mistaken for a simple literary reading or with pedagogical

22 "Concilium Nicaenum Secundi", in IOANNES Dominicus MANSI, Sacrorum Conciliorum nova et amplissima collectio, vol. 13, col.300C; also see S. BASILIUS MAGNuS, "Homilia XIX, In Sanctos quadraginta martyres", in J.P. Migne, PG. vol. 31, col.507526, here col.510A.

${ }^{23}$ DANIEL, Evanghelia slavei lui Hristos..., p. 398.

${ }^{24}$ Dumitru STĂNILOAE, "Considerații în legătură cu Sfintele Icoane" (Viewpoints on the Holy Icons), in Biserică Misiune Slujire (Church, Mission, Ministration), Galați, Archbishopry of Dunărea de Jos Press, p. 76-98, here p. 78.

${ }^{25}$ Triod (Triodion), Bucureşti, IBMBOR Ph., 1986, p. 183.

${ }^{26}$ DANIEL, Evanghelia slavei lui Hristos..., p. 394.

${ }^{27}$ Ene BRANIȘTE, "Teologia Icoanelor" (Icon Theology), in Studii Teologice (Theological Studies), no. 3-4/1952, p. 175-201, here p. 186.

28 Dumitru STǍNILOAE, "Introducere" (Introduction), in Wilhelm NysSEN, Inceputurile picturii byzantine (The Beginnings of Byzantine Painting), translated by D. Stăniloae, Bucureşti, EIBMBOR Ph., 1975, p. 8. 
concern, but we must say that each icon literally speaks about the Grace of God-Man and whoever looks at it experiences this and discovers the power of the Holy Spirit. We are told this in the clearest manner by St. Ioannes Damascenus, who says:

"Once God without a body or shape was not at all painted. Yet, now, because God reveled Himself in body, He lived with people, I can paint an icon of the visible God. I do not worship matter, but the Creator of matter, who became matter for me, who accepted to live within matter, and who used matter to work on my salvation. I will not cease to honour the matter by which salvation found me...Isn't the wood of the cross matter...the holy and respected mountain...the ink and the book of the Gospel...? And don't our Lord's Body and Blood matter? Or take away the value and worship of all these! Or acknowledge, according to the Church traditions, the worship of icons that are sanctified in God's name and His friends, and for this reason filled with the grace of the Holy Spirit. Do not think of matter as unworthy, as it ought not to be despised. Nothing that God did is worth despising. This is the opinion of Manicheism followers"29.

Consequently, iconography is part of Church tradition, a means of conveying and expressing the divine Revelation, having the same liturgical, dogmatic and educational significance as Holy Scripture $^{30}$. Orthodox iconography expresses the truth of the Church, a truth that the human language embellished by words, about aspects connected, for example, to the economy of salvation describing facts, people and events that concurred to its fulfillment. The icon always reunites dogmatic meaning and moral understanding:

"Incredible joy, the power of faith and the capability of living become, for us, the reason for respecting and kissing the faces depicted in the sacred images. Seeing God's face is joy to us, - St. Nicephorus of Constantinople says - the foundation of the truth of dogmas and of all that has been done for us in the economy of salvation [...] this is Orthodox Theology, [...] this is the language of church iconograph"31.

${ }^{29}$ S. IoAnnes Damascenus, 'De imaginibus. Oratio I', in J.P. Migne, PG. Vol. 94, col. 1232-1284, here col.1245BCD.

${ }^{30}$ L. USPENSKI, Teologia icoanei..., p. 64;65.

31 ST. Nicephorus, "Antirrhetici tres adversus Constantinum Copronymum", in JP. 
That is why, as a work of art, the icon is neither an absolute, nor an annex, but a continuous and complete expression of faith ${ }^{32}$ and a constant proclamation of divine economy. The icos during the matins on Orthodoxy Sunday reveals the mystery that we are the beneficiaries of this divine economy, which the prophets of the Old Testament wrote about, and we thus become aware of the fact that salvation comes by confessing faith, by facts, words and behaviour, in Christ, our Lord, of the Holy Trinity within which we are baptized: "This Mystery of the economy, being inspired by God, a long time ago, the prophets, and acquiring its glory, have foreseen it for us, who have reached the end of time. Hence, by it acquiring divine knowledge, we acknowledge one God worshipped in His three divine faces; and to Him alone pledging our lives, having one faith and one baptism, in Christ we became clothed. Thus, we confess to salvation, in fact and word, we envisage it" $^{\prime \prime 3}$. Therefore, the icon is not mere image, but it gives us the feeling of God's real presence, a sort of "theophany," even if an imperfect one ${ }^{34}$. From this point of view, the Byzantine icon is a living testimony of God and of His love for all. The icon of Christ is not only an image of Jesus the man, but, on the contrary, of God who "became man for us and for our salvation."

While a Western Renaissance painting may be considered a window opened onto the world of senses representing an outburst of the space in front of us, being a reproduction of nature ${ }^{35}$, on the contrary, the Byzantine icon represents a spiritual exposure to the presence of God, of the Saints depicted ${ }^{36}$. The Christian discovers, in the icons of saints, the certainty that everything taught by the Church is achieveable. The saints, who were human beings themselves, as we are, with sins and mistakes, lived evangelic lives and received the gift that worked on their holy dimension. This is why life within Christ that we worship in the icons is not a utopia, but a reality and, consequently, the icons of saints

Migne, $P G$. vol. 100, col. 282, note 40 .

32 DANIEL, Evanghelia slavei lui Hristos..., p. 394.

${ }^{33}$ Triod (Triodion), 1986, p. 183.

${ }^{34}$ E. BRANișTe, “Teologia Icoanelor”, p. 191.

35 D. StĂniloAe, "Considerații în legătură cu Sfintele Icoane" (Viewpoints of the Holy Icons), p. 93.

${ }^{36}$ A. AmAto, Gesu il Signore, p. 356. 
do not have a decorative role in the church, but they convey the idea that holiness is within the reach of all people. The holy icons first display the function of guiding and strengthening into the right faith. They have an educational and gracious role ${ }^{37}$. They imprint, in the mind and memory of believers, the teachings of God of the Holy Trinity, Christ's salvation deeds, Virgin Mary's place within the economy of the Son's Embodiment, the richness of faith in Christ, in the saints, as an urge to our holiness $^{38}$. The icon - St. Theodorus Studita tells us -

"shows Christ to us in His birth, performing miracles, crucified, buried, resurrected, and ascending to Heaven. In all these, we are not mistaken as if all of these had never taken place, as sight accompanies mental contemplation and by both - our faith is strengthened in the mystery of the embodiment" 39 .

Saint Ioannes Damascenus says that the very reason why the icon exists is exactly that of being a guide to the conscience ${ }^{40}$ and of reminding people of God's works:

"Generally, the icon was made to be useful, to do good and to achieve salvation, for us to become aware of hidden things, because things are made visible and interpreted, and thus for us to desire and covet good things, and avoid and hate the opposite ones, the evil hings" 41 . "The icons were put in place to warn by their grace, not as gods, but as things that remind us of the divine works" $"$.

\section{The icon, a mysterious presence of the depicted}

By depicting Christ, His Mother and the saints on icons, the

37 Ștefan C. AlEXE, "Sensul Icoanei la Sfântul Ioan Damaschin și Sinodul VII ecumenic (Niceea, 787)" (The Meaning of the Icon with Saint Ioannes Damascenus and the $7^{\text {th }}$ Ecumenic Synod (Nyceea, 787)), in Biserică Misiune Slujire (Church, Mission, Ministration), Galați, Archbishopry of Dunărea de Jos Press, p. 99-113, here p. 106.

${ }^{38}$ DANIEL, Evanghelia slavei lui Hristos, p. 399.

${ }^{39}$ S. TheOdorus Studita, "Refutatio et Subversio. Impiorum Poematum", in J.P. Migne, $P G$. vol. 99, col.435-476, here col.455C.

${ }^{40}$ E. BRANișTE, “Teologia Icoanelor”, p. 181.

${ }^{41}$ S. IoAnnes Damascenus, 'De imaginibus. Oratio III', in J.P. Migne, PG. Vol. 94, col.1317-1420, here col.1338C.

42 IDEM, 'De imaginibus. Oratio I', col.1247D. 
Orthodox Church only emphasizes the Church place as a copy of the old Eden, according to St. Nicephorus of Constantinople:

"In this way, we can see the Church as an ever-green, universal Paradise, as we can see many beauties in Eden, with various plants having in their centre the Tree of life, in the same way the holy icons of the saints, which we worship, have at their core the immaculate icon of the Lord and of His Mother",43.

That is why the Orthdox place of worship cannot be conceived of without icons because everything acquires life and meaning by means of the icon. The icon is considered to be a living presence, an exposure to the presence of God and of the Saints. The iconostasis of the church is a "living wall", "the border between the seen and the unseen world," a vision because it asks us to contemplate the presence of God and of the Saints in an iconographic way ${ }^{44}$. The icon does not only represent the mere memory of a fact, of a face, but it is the sign of an actual presence. In this sense, we may understand what St. Theodorus Studita says when he states that

"The propotype is not in the icon as being, otherwise the icon would also be called prototype, and, vice versa, the prototype would be called icon. This would, however, be absurd, as each nature (that of the model and that of the icon) has its very own definition; the prototype is thus in the icon due to resemblance to being" 45 . St. Iohannes Damascenus explains it even better to us when he says: "God's Grace hovers above the icon because, during their lives, the saints were full of the Holy Spirit. Equally, after their death, the Grace of the Holy Spirit stays forever in their souls, in their bodies buried in the graves, in the features and their holy faces, and this happens not due to nature, but as a result of divine grace and work" $" 46$.

It is obvious that such mysterious presences in the icon indicate the very presence of Christ, of the Lord's Mother and of the Saints in God's Grace and they are strongly connected to other equally

${ }^{43}$ S. NiCEPHORUS, “Antirrhetici tres adversus...”, col. 344D, note 83.

44 Pavel FloRENSKI, Iconostasul (Iconostasis), translated and chronology by Boris Buzilă, Bucureşti, Anastasia, 1994, p. 156.

45 ST. TheOdorus Studita, "Refutatio et Subversio. Impiorum Poematum”, col.420D.

${ }^{46}$ ST. IoAnnes Damascenus, "De imaginibus. Oratio I', 19, col.1249. 
ARS LITURGICA. From the Image of Glory to the Images of the Idols of Modernity mysterious presences, such as Christ's real presence in the Eucharist and the other Holy Mysteries of the Church, but also in the Word of the Gospel and the prayer of the Church. As a consequence, both the icon and the rest are an invitation to dialogue and communion.

\section{The icon painter and the importance of the iconographic program}

For an icon to reach this dimension of being a real presence of the depicted, the hagiographer (the painter) must be more interested in conveying the theological and liturgical message than in highlighting technique and colors. By its bi-dimensional representation of the subject, the icon must take the painter out of the natural reality of the three dimensions. This is about a certain and clear theological choice operated by the painter. The bi-dimensionality is the instrument by which the painter may represent a vision ${ }^{47}$. From here there derives the spiritual and almost sacerdotal outlook of the hagiographer. This happens because what he achieves by the icon is a profound theological fact, and his life must be spiritualized for him to see the divine reality that he must depict in the icon. The icon-maker must strip his art of any individual element ${ }^{48}$ and he must let himself be carried away by the inspiration of the Holy Spirit, imposing onto himself not only a material ascesis, but one of the eyes, to avoid futile and deceptive colors ${ }^{49}$. Only thus will he be able to "see" the divine reality that he must represent in the icon. Only thus does the icon avoid being considered to be a fantastic or artistic concept of the prototype represented, but an expression of a mystic reality. There is nothing arbitrary in painting an icon, nothing is left to the artist, but the icon observes a ritual established by Church teaching, with the very purpose of rendering the prototype as faithfully as possible and of inducing mystic experience in the looker-on. To this end, the icons in the Orthodox Church are not only mere paintings that depict faces of events or holy people, but they are an expression of the Church teachings, and what sets them apart from any art in general is not the subject, but the representation style.

47 Pietro Galignani, Mistero e immagine. L'icona nella tradizione bizantina, La Casa di Matriona, 1981, p. 65.

${ }^{48}$ L. USPENSKI, Teologia icoanei (Icon Theology), p. 30.

${ }^{49}$ A. Амато, Gesu il Signore, p. 357. 
The style itself is not arbitrary, or one that could be adapted to artistic necessities or trends belonging to various historical times, but it must be one which could represent the inner content of the people depicted. The Fathers in the $7^{\text {th }}$ ecumenic Synod state this very clearly: "The style of icons is not the painters' invention, but the approval of the institution and tradition of the Universal Church"

In the case of the icon, what is important is the teaching of the Church, as the icon has to confess the right faith of the Church. That is why, according to the tradition of the Church, it is not anybody who can paint icons, but only those who prove to have the right faith by means of a dignified and moral life ${ }^{51}$. From this point of view, we can speak about a calling, a spiritual vocation of the hagiographer. As iconographic art is profoundly an art that expresses Church theology, the painter must as well be a spiritual man, touched and enlightened by the grace of the Holy Spirit. To better understand this calling of the painter, we must only look at the Transfiguration Icon and we will comprehend that the painter depicting this moment in Christ the Saviour's life must display exceptional spiritual maturity and capability ${ }^{52}$. What one must notice in this icon is exactly the rendering of the Tabor light that must prevail over the natural one, and which gives the icon its eschatological dimension.

\section{Conclusions}

Making an icon, even from the perspective of technical achievement, is a real act of faith and not only that, it reflects, at the

50 "Concilium Nicaenum secundi", in Ioannes Dominicus MANSI, Sacrorum Conciliorum nova et amplissima collectio (hereinafter MANSI), vol. 13, col. 251BC: "Non est pictorum adinventio imaginum factura, sed catholicae ecclesiae approbabilis legislatio et traditio."

51 The 869-870 Synod, at the time of Patriarch Ignatius, directed against St. Fotie, the patriarch of Constantinople and considered in Rome as the 8th Ecumenic Synod by canon 7, forbids leading immoral lives to paint icons. Cf. "Sancta Synodus Octava Generalis, Constantinopolitana Quarta", in MANSI, vol. 16, col.1-534, here col. 402; also see L. UsPENSKI, Teologia icoanei, p. 95; also see Regulamentul pentru organizarea și funcționarea Comisiei de Pictură bisericească a Patriarhiei Române (Regulations for the organization and functioning of the Painting Board within the Romanian Patriarchy), Bucureşti, 2012, ch. VI, art. 129, leter m).

52 Gervais DumeIGE, Nicee II, Paris, Edit. de l'Orante, 1978, p. 185-206. 
same time, the mystic experience of the whole Church. In this respect, St. Ioannes Damascenus:

"Tell me, Christian, if a pagan were to come to you saying: 'Show me faith, so that I might believe as well' - what will you show him? Will you, by any chance, raise him from the level of the seen to that of the unseen? Take him into a church (...) and place him in front of the icons painted there" ${ }^{, 53}$.

The personal spiritual experience of an icon-maker expressed in the accuracy to preserve the faith and teaching of the Church in making the icon cannot be perceived by the looker-on, but it can be perceived in the life of the Church and it can be verified by the Church. Teofan Grecul $^{54}$, Andrei Rubliov and other master icon-craftsmen of the past also had a profound inner life. Yet they did not depict themselves, but their icons are deeply rooted in the Church tradition, which embraces the entire century-old experience of the Church. Many icon-makers were great contemplative mystic men as well.

The same way as a profane work talks about the sensitive and emotive world in a personal manner of the artist, the Orthodox icon represents the reality of the Kingdom of God, which is not worldly, in a manner of the teaching displayed by the Church throughout time. From this point of view, the icon is both a path to and a means of confessing the faith of the Church towards man's deification.

\section{References:}

1. ALEXE, Ștefan C., "Sensul Icoanei la Sfântul Ioan Damaschin și Sinodul VII ecumenic (Niceea, 787)" (The Meaning of the Icon with Saint Ioannes Damascenus and the $7^{\text {th }}$ Ecumenic Synod (Nyceea, 787)), in Biserică Misiune Slujire (Church, Mission, Ministration), Galați, Archbishopry of Dunărea de Jos Press, p. 99-113.

2. Aмato, Angelo, Gesu il Signore. Saggio di cristologia, Bologna, Edizioni Dehoniane, 1999.

3. BAGGleY, John, Porți ale veșniciei. Icoanele și semnificația lor

${ }^{53}$ S. IOANNES DAMASCENUS, "De sacris imaginibus adversus Constantinum Cabalinum", in J.P. Migne, $P G$., vol. 95, col.310-354, here col.325CD:

${ }^{54}$ Byzantine painter (about 1335 - 1410), mentor and professor of Andrei Rubliov. 
duhovnicească (Gates to Eternity. Icons and Their Spiritual Significance), Bucureşti, Sophia, 2004.

4. BRANISTE, Ene, Liturgica specială (Special Liturgics), Bucureşti, IBMBOR, 1980.

5. BRANISTE, Ene, "Teologia Icoanelor" (Icon Theology), in Studii Teologice (Theological Studies), no. 3-4/1952, p. 175-201.

6. CAtella, Alceste, "Eucaristia Domenicale vertice della vita cristiana", in Rinaldo Falsini, Il mistero cristiano e la sua celebrazione, Milano, Edizioni OR., 1994, p. 66-85.

7. Ciubotea, Daniel, Evanghelia slavei lui Hristos. Predici la Duminicile de peste an (The Gospel of Christ's Glory. Sermons on Sundays Over the Year), Bucureşti, Basilica, 2016.

8. "Concilium Nicaenum secundi", in IOANNES DoMINICUS MANSI, Sacrorum Conciliorum nova et amplissima collectio, vol. 13, col.1-658.

9. Costin, PS. VASILE Targovisteanul, "Sfintele icoane în credința și evlavia ortodoxă" (The Holy Icons in the Orthodox and Faith and Piety), in Indrumator pastoral (Pastoral Guidelines), Bucureşti, Dioecese of București, 1981, p. 83-86.

10. DRĂGHICENOIU, Laurențiu, "De la simbol la icoană" (From the Symbol to the Icon), in Glasul Bisericii (The Voice of the Church), no. 1-6/2011, p. 155-184.

11. DumeIGe, Gervais, Nicee II, Paris, Edit. de l'Orante, 1978.

12. DURĂ, Ioan, "Icoană și Liturghie" (Icon and Liturgy), in Ortodoxia (Orthodxy), year XXXIV, no. 1/1982, p. 84-89.

13. Evdokimov, Pavel, Ortodoxia (Orthodoxy), Bucureşti IBMBOR, 1996.

14. FlORENSKI, Pavel, Iconostasul (Iconostasis), translated and chronology by Boris Buzilă, Bucureşti, Anastasia, 1994.

15. FlorovskiJ, Georgij, "The Elements of Liturgy", in P. EDWALl, E. HAYMANN, Wd. MAXWELL, Ways of Worship, London, 1952.

16. Galignani, Pietro, Mistero e immagine. L'icona nella tradizione bizantina, La Casa di Matriona, 1981.

17. Gatti, Vincenzo, "Arte", in Dominico Sartore e Achile M. Triacca, Nuovo Dizionario di Liturgia, Milano, San Paolo, 1988.

18. GHARIB, Georges, Le icone festive della chiesa ortodossa, Milano, Ancora, 1985.

19. Liturghier (Missal), Bucureşti IBMBOR, 2000.

20. QUENOT, Michel, Icoana. Fereastră spre absolut (The Icon. Window 
towards the Absolute), București, Enciclopedică Ph., 1993.

21. Regulamentul pentru organizarea și funcționarea Comisiei de Pictură bisericească a Patriarhiei Române (Regulations for the organization and functioning of the Painting Board within the Romanian Patriarchy), Bucureşti 2012.

22. S. BASILIUS MagnUS, "Homilia XIX", Sanctos quadraginta martyres, in J.P. Migne, $P G$. vol. 31, col.507-526.

23. S. Dionysius Areopagita, De divinis nominibus, in J.P. Migne, PG. vol. 3, col.586-996.

24. S. IoAnnes Damascenus, "De imaginibus. Oratio I", in J.P. Migne, $P G$. vol. 94, col.1232-1284.

25. S. IoAnnes Damascenus, "De imaginibus. Oratio III", in J.P. Migne, $P G$. vol. 94, col.1317-1420.

26. S. IOANNES DAMASCENUS, "De sacris imaginibus adversus Constantinum Cabalinum", in J.P. Migne, $P G$, vol. 95, col.310-354.

27. S. NICEPHORUS, Archiepiscopi Constantinopolitani, "Antirrhetici tres adversus Constantinum Copronymum", in JP. Migne, PG. vol. 100, col.206-534.

28. S. TheOdorus StUdiTA, "Refutatio et Subversio. Impiorum Poematum", in J.P. Migne, PG. vol. 99, col.435-476.

29. "Sancta Synodus Octava Generalis, Constantinopolitana Quarta", in IOANNES DOMINICUS MANSI, Sacrorum Conciliorum nova et amplissima collectio, vol. 16, col.1-534.

30. STĂNILOAE, Dumitru, "Considerații în legătură cu Sfintele Icoane" (Viewpoints on the Holy Icons), in Biserică Misiune Slujire (Church, Mission, Ministration), Galați, Arhiepiscopia Dunării de Jos, p. 76-98.

31. STĂNILOAE, Dumitru, "Introducere" (Introduction), in Wilhelm NYSSEN, Inceputurile picturii byzantine (The Beginnings of Byzantine Painting), translated by D. Stăniloae, Bucureşti, EIBMBOR, 1975.

32. STREZA, PS. LAURENȚIU, "Cinstirea lui Dumnezeu. Cultul și formele lui" (Honoring God. The Denomination and Its Forms), in Credința ortodoxă și viața creștină (Orthodox Faith and Christian Life), Sibiu, 1992, p. 223-259.

33. Triod (Triodion), Bucureşti, IBMBOR, 1986.

34. USPENSKI, Leonid, Teologia icoanei în Biserica Ortodoxă (Icon Theology in the Orthodox Church), Apologeticum, 2006.

35. Vagaggini, Cipriano, Il senso teologico della liturgia, Milano, San Paulo Ph., 1999. 
36. VALDMAN, Traian, "La celebrazione eucaristica culmine della vita comunionale ortodossa", in Eucaristia sfida alle Chiese divise, Padova, Messaggero, 1984, p. 151-175.

37. ZIZIOULAS, John, Eucaristia e Regno di Dio, Magnano (BI), Qiqajon-Bose, 1996. 